Aslı Güler *

\section{Does Monetary Policy Credibility Help in Anchoring Inflation Expectations? Evidence from Six Inflation Targeting Emerging Economies $^{1}$}

\begin{abstract}
Most emerging market central banks have adopted inflation targeting as their monetary policy system. The heart of inflation targeting system is inflation expectations. The success of a central bank in achieving targets depends on to the extent to which inflation expectations are formed by the announced targets. As the credibility of the central bank increases, its ability to affect the public expectation also increases. The public adjusts its inflation expectations based on announced inflation target only in case of that they believe that the central bank has the sufficiency to reach the inflation target. Credibility enables expectation to be formed in a forward-looking way by weakening its connection with the past. This study aims to contribute to the literature concerning the effects of credibility on monetary policy. For this purpose, using data of six emerging inflation targeting economies (Turkey, Brazil, the Czech Republic, Chile, Poland, and South Africa), the empirical tests were carried out in order to understand the effect of the credibility on the behaviour of inflation expectation in emerging economies. The findings denote that credibility is quite relevant to reduce inflation expectations and contributes to the strength of inflation targets being an anchor for inflation expectations.
\end{abstract}

Keywords: Credibility, Inflation Expectations, Nominal Anchor, Inflation Targeting.

JEL Code: E31, E52, E58.

1 A draft version of this paper was presented at II. International Conference on Empirical Economics and Social Sciences (ICEESS' 19).
${ }^{*}$ Ordu University,

Department of Economics,

Ordu, Turkey

Email:

asliguler24@hotmail.com 


\section{Introduction}

This article provides a perspective on the anchoring effect of monetary policy credibility based on economic theory and empirical evaluation. The last 30 years of literature on monetary policy points out that credibility is very crucial to the success of disinflation policies. Monetary policy credibility that is nominated as the key element in modern monetary policy literature is often used to refer to the central bank's ability to manage inflation expectations of economic actors. Expectation is the belief of economic actors about what the future brings and the confidence in central bank' ability to reach its goals, namely the credibility (Demertzis \&Viegi, 2016). While the analysis presented here towards understanding the role of credibility is based on six inflation targeting emerging economies, I believe that the results comprise broadly to most inflation targeting emerging economies.

Over the past three decades, many central banks have adopted inflation targeting system as a monetary policy framework to manage price stability. Central banks are able to overcome the problem of lack of confidence and strengthen their credibility under inflation targeting by announcing a strong commitment to the target and implementing monetary policy in accordance with its target (Aguir, 2018). In this system, a central bank estimates a numerical "target" or "target range" for inflation over a specific horizon and announces it to the public ${ }^{2}$, then makes a strong commitment to attempt directing actual inflation toward target inflation. The main concern behind this is to keep inflation expectations under an anchor via the target (Johnson, 2002). In the next stage, the only thing the central bank has to do is to match what it says and what it does. ${ }^{3}$ If the central bank adjusts its short term policy interest rate by rationally and timely decisions in accordance with inflation target, the central bank would have built credibility. Building credibility makes easier for the central bank to manage economic agents' inflation expectations.

What is credibility? The term 'credibility' is defined in a variety of different ways in the monetary policy literature. In effect, credibility is a quality assessment of monetary policy implementation. Cukierman and Meltzer (1986a) define credibility as "the absolute value of the difference between the policymaker's plans and the public's beliefs about those plans". this definition implies that the smaller

\footnotetext{
2 Svensson (1997), argues that inflation targeting is essentially an "inflation forecast targeting" since inflation targeting is a system in which the central bank's inflation forecast becomes an explicit intermediate target.

3 Let's remember Alan Blinder's famous words "Credibility is built by matching deeds to words".
} 
the difference, the greater the credibility of monetary policy. Blinder (1999) says that "a central bank is credible if people believe that it will do what it says". According to Friedman (2002), "a credible central bank is one that is believed to be firmly committed to low inflation". On the other hand, credibility is also defined and measured by the degree to which inflation expectations are anchored on a specific inflation target. For example, as for Svensson (2009), "the credibility of an inflation targeting regime is usually measured by the proximity of privatesector inflation expectations for different time horizons to the inflation target". In terms of this approach, the closer the expectations are to the target, the higher the degree of credibility.

How can a central bank create or enhance credibility? The theoretical literature suggests that a central bank can gain credibility by being bound by a policy rule annihilating the possibility of time inconsistency. Though Taylor (1983) and Barro \& Gordon (1983) claimed that in the absence of constitutional enforcement, policy rules will not bring credibility because they are not dynamically consistent. Central bank's powers and duties should be enhanced by law. On the other hand, Cukierman \& Meltzer (1986a) argue that the absence of a binding constitutional rule is not the only reason for imperfect credibility. A policymaker's imperfect control of money, changing objectives, and an incentive to maintain some degree of ambiguity can be the reasons behind imperfect credibility. On the other hand, central bank independence helps the central bank to keep its promise about inflation targets by facilitating to determine objectives and instruments for monetary policy implementation, without the influence of the government or another institution or individual (Radović, Radonjić, \& Đurašković, 2018).

Monetary policy affects the cycle not only by directly affecting aggregate demand and supply but also by shaping expectations (Martin, 2020). As pointed out in a huge amount of literature, the success for a central bank depends on the extent to which the expectations of the public are reshaped by the announced targets that is used as an imaginary wand to anchor inflation expectations. This is a point that deserves attention. The announcement of targets is necessary but not sufficient. The unique complementary condition for success in anchoring inflation expectations is credibility.

The growing interest in the credibility of monetary policy announcements is partly based on the revolution of rational expectations. While the assumptions of the rational expectations hypothesis are valid, a completely credible central bank can reduce inflation thanks to its strong ability managing inflation expectations, without creating a negative impact on employment (Blinder, 1999). How to achieve this performance? No doubt, the key element of this process is credibility. 
If prices which are determined today reflect future expectations, inflation can be deflated by reducing inflation expectations without the need to raise interest rates. Hereby, the anti-inflationary process costs minimum production and employment losses. Hence, the more credible the monetary policy, the lower the social cost.

The essence of credibility is the public belief in the possibility of achieving the central bank's previously announced targets. There is no doubt that credibility is a forward-looking concept and is directly linked to expectations. As for inflation targeting, inflation expectations lie in the core of this system. If the success of the anti-inflationary policy is linked to lower social cost or sacrifice ratio, then inflation expectations need to be managed well. Only in the case that the public believe that the central bank's capability to reach announced targets can inflation be lowered without cost. Thus, how the public responds to the announced targets is the main concerns of monetary policymakers in the inflation targeting system. Only if credibility exists, the public believes in the central bank and forms its expectations based on the announced inflation targets and inflation expectations are anchored. Otherwise, inflation expectations cannot be anchored and act together with past inflation rates (de Mendonça, 2018).

This study aims to question empirically how much credibility contributes to the anchoring strength of inflation targets by using data from six developing countries. The rest of the study is organized as follows. The section below addresses empirical studies in the literature. The third part deals with the issue of measurement of monetary policy credibility and a time-varying index has been created for the sample countries. Section 4 presents empirical shreds of evidence in order to understand whether monetary policy credibility is significate on the behaviour of inflation expectations and how much credibility associated with inflation targets contribute to anchor inflation expectations. The last section summarizes and concludes.

\section{Literature Review}

After being introduced inflation targeting as a monetary policy strategy, the empirical literature on the behaviour of inflation expectations has expanded. If inflation expectations behaviours are meant to be addressed, the issue is directly linked to inflation expectations and monetary policy credibility. Therefore, there exist a number of empirical studies both for developed and emerging countries attempting to provide evidence on the impact of monetary policy credibility on the behaviour of inflation expectations and the ability of inflation targets to an- 
chor expectations. While some studies addressed the direct relationship between inflation targets and expectations, the others focus on whether the monetary policy credibility has changed the relationship between them. It should be noted that empirical studies, whether for developed countries or emerging countries, have produced largely consistent results implying that the credibility improves outcomes of the monetary policies. However, the number of studies dealing with emerging countries remains limited.

Johnson (2002) investigated the change of inflation expectation behaviour using a panel method for five inflation targeting and six non-inflation targeting countries and found that inflation expectations fall following the announcement of the targets. Likewise, Johnson (2003) also investigates the effect of inflation targets on expectations in five industrialized countries. In his paper, it is evidenced that targets reduced the level of expected inflation except for United Kingdom.

Levin, Natalucci \& Piger (2004), analysed the behaviour of medium- and longterm inflation expectation and persistence for inflation (CPI) for inflation targeting and non-inflation targeting countries in the period 1994 and 2003. They found that inflation targeting plays an important role in anchoring inflation expectations. In addition, according to the findings, while in non-inflation targeting economies, inflation expectations are highly sensitive to past inflation rates, in contrast, in the inflation targeting economies, there is almost no relationship between inflation expectations and past inflation rates.

Gürkaynak, Levin \& Swanson (2006) investigated the anchoring effect of inflation targeting on long-run inflation expectations by comparing inflation targeters and non-inflation-targeter industrialized countries. Regressions performed on different periods for each country provides evidence supporting the view that a credible inflation target helps to anchor expectations.

Tanuwidjaja \& Choy (2005) constructing a small-scale macroeconomic model of a forward-looking nature for Indonesia, performed a deterministic and stochastic econometric simulation to investigate the role of central bank's credibility in procuring the acquisition the inflation target. The findings imply that zero credibility is undesirable in any case for Indonesia. Moreover, it is found that the level of credibility plays an essential role in achieving inflation target much faster.

Croitorov (2009) addressed the effects of monetary policy credibility of Kazakhstan and Moldova with a simulation analysis conducted using quarterly data for the period 2000 - 2007. For this purpose, by building a small macroeconomic model in which inflation expectations are forward-looking, the period of time in 
which the macroeconomic variables approach the long-term values is estimated at different credibility levels. According to the results of the study, under low monetary policy credibility, inflation achieves its target in a period twice as long. In addition, the inflation target, accompanied by a full credible commitment, can reduce inflation much faster, comparing to a non-credible one. The most striking result of the study is that it is not necessary for the central bank to gain full credibility in order to shorten the disinflation process. It is enough for a central bank to provide strong commitment related to inflation targets in order to bring inflation down much faster.

Yuxiang \& Chen (2010), using the empirical analysis based on a large-scale survey for Chine in 2008, analysed the role of monetary policy credibility on individuals inflation expectations. They found evidence implying that when price is rising, perceived policy credibility can stabilize inflation expectations.

Demertzis, Marcellino \& Viegi (2010) analysed the strength of the link between past inflation and inflation expectations, and anchoring of inflation expectations to the announced inflation targets by using the VAR model for European countries in the period after 1999. It is found that past inflation rates and inflation expectations have been less dependent for the last decade and that the announced inflation targets aid to anchor inflation expectations at the desired level. However, findings indicated that the anchor strength is not constant.

Issler \& Santos (2018) investigated the relationship between central bank credibility and inflation expectations by estimating the heteroscedasticity and autocorrelation consistent (HAC) covariance matrix and using Generalized Method of Moments (GMM) for the Brazilian economy. The paper found that the credibility helps to re-anchoring of long-term inflation expectations in all horizons.

Using OLS estimations based on seven inflation targeting emerging economies, de Mendonça (2018) analyses the association of credibility with inflation expectations. The main result of the study, which provides evidence that credibility can be correlated with inflation expectations, is that the transition to inflation targeting is not a sufficient condition for anchoring inflation expectations. Moreover, findings signify that low credibility performance leads to the predominance of the backward-looking behaviour in the formation of inflation expectations. 


\section{Measuring Monetary Policy Credibility}

Credibility issue, first systematically examined by Kydland \& Presscott (1977) and Barro \& Gordon (1983) has become the subject of more and more studies. So, the number of initiatives to measure credibility has increased in the recent monetary policy literature. Since it is not an objective and quantitative concept, credibility is hard to specify and even more difficult to measure in practice. Nevertheless, credibility has been tried to be quantified, based on two different approaches in the empirical literature. The first is credibility creation approach and the other one is the credibility impact approach.

Credibility creation approach is a quantification of the factors that influences central bank credibility such as central bank independence, transparency, accountability, the conservativeness of head of the central bank, history of honesty, history of fighting inflation, constrained by a rule, small fiscal deficit or debt, success in achievement of inflation targets, good governance. To date, many studies used central bank independence as a proxy of credibility. However, this approach is impractical and its results can be unreliable because the factors thought to affect credibility are more steady individually, comparing with credibility influenced by many factors (Mackiewicz-Łyziak, 2016; Blinder, 1999; Doğan \& Bozdemir, 2014).

According to the credibility impact approach, credibility is quantified based on factors such as inflationary expectations and long-term interest rates. Compatible with the definition of credibility, empirical studies based on this approach uses inflation expectations as the simplest measure of credibility. In this method, credibility is measured either by the degree of deviation of inflation expectations from the inflation target or by the weight of the inflation target attached by economic agents during the formation of inflation expectations. In this context, it seems possible to measure the credibility of the inflation target announced by the central bank in t-1 period with the deviation of inflation expectations from this target (Eq. 1). If it is assumed that the central bank announces a zero inflation target for period $t$ in the period of $t-1$, the socially optimal policy implies zero expected inflation. Thus, the credibility of the zero-inflation target announcement in period $t-1$ can be measured by the negative of the absolute value of the deviation of inflation expectations from zero. In this case, the closer the inflation expectations to zero, the higher the credibility and vice versa (Faust \& Svensson, 2001).

$$
c_{t-1} \equiv-\left|t_{t \mid t-1}\right|
$$


This expression is called as "the average credibility of announcements" by Cukierman \& Meltzer (1986b) ${ }^{4}$. According to this, "average credibility is inversely related to the distance between the current target announcements and the public's beliefs". Credibility indices derived based on the credibility impact approach reflect the fundamental relationship between credibility and inflation expectations, that is, expectations from targets. According to these indices, credibility changes inversely with the degree of deviation of inflation expectation $[\mathrm{E}(\pi)]$ from inflation target $[\pi]$. In this study, the credibility series are calculated using a wellknown index proposed by Cecchetti \& Krause (2002). The index is defined as below:

$$
\left\{\begin{array}{ll}
1 & \text { if } E(\pi) \leq \pi^{t} \\
1-\frac{1}{0.2-\pi^{t}}\left[E(\pi)-\pi^{t}\right] & \text { if } \pi^{t}<E(\pi)<0.2 \\
0 & \text { if } E(\pi) \geq 0.2
\end{array}\right\}
$$

According to this index, monetary policy credibility takes values between 0 (no credibility) and 1 (full credibility). If expected inflation is equal or less than the inflation target, the credibility index takes the value of 1 . At the other extreme, if expected inflation exceeds 0.2 , the index gets the value of 0 . Finally, if expected inflation is between the inflation target and 0.2 (higher than the former, and lower than the latter), the credibility index takes a value between 0 and 1 . In this index, the value of 0.2 is assumed to be the threshold at which monetary policy loses control and thus credibility completely.

In this study, 12 months ahead inflation expectations are used for estimation of the credibility index for each country. Figure 1 illustrates the credibility index calculated by using Eq 2. for each country. It is seen that credibility performance of the countries is not brilliant. However, the worst credibility performances belong to Turkey and South Africa of which average credibility values are 0.86 and 0.88 , respectively. It is seen that although showing regular improvement until the end of 2009, Turkey's credibility index declined steadily as of early 2010. In the case of South Africa, the credibility index presents its worst performance in 2008, then gains stability.

4 Cukierman \& Meltzer (1986b:40) have proposed another measure of credibility called marginal credibility measuring the extent to which a one-unit change in announced targets affects expectations. 
Figure 1: Monetary Policy Credibility Indices
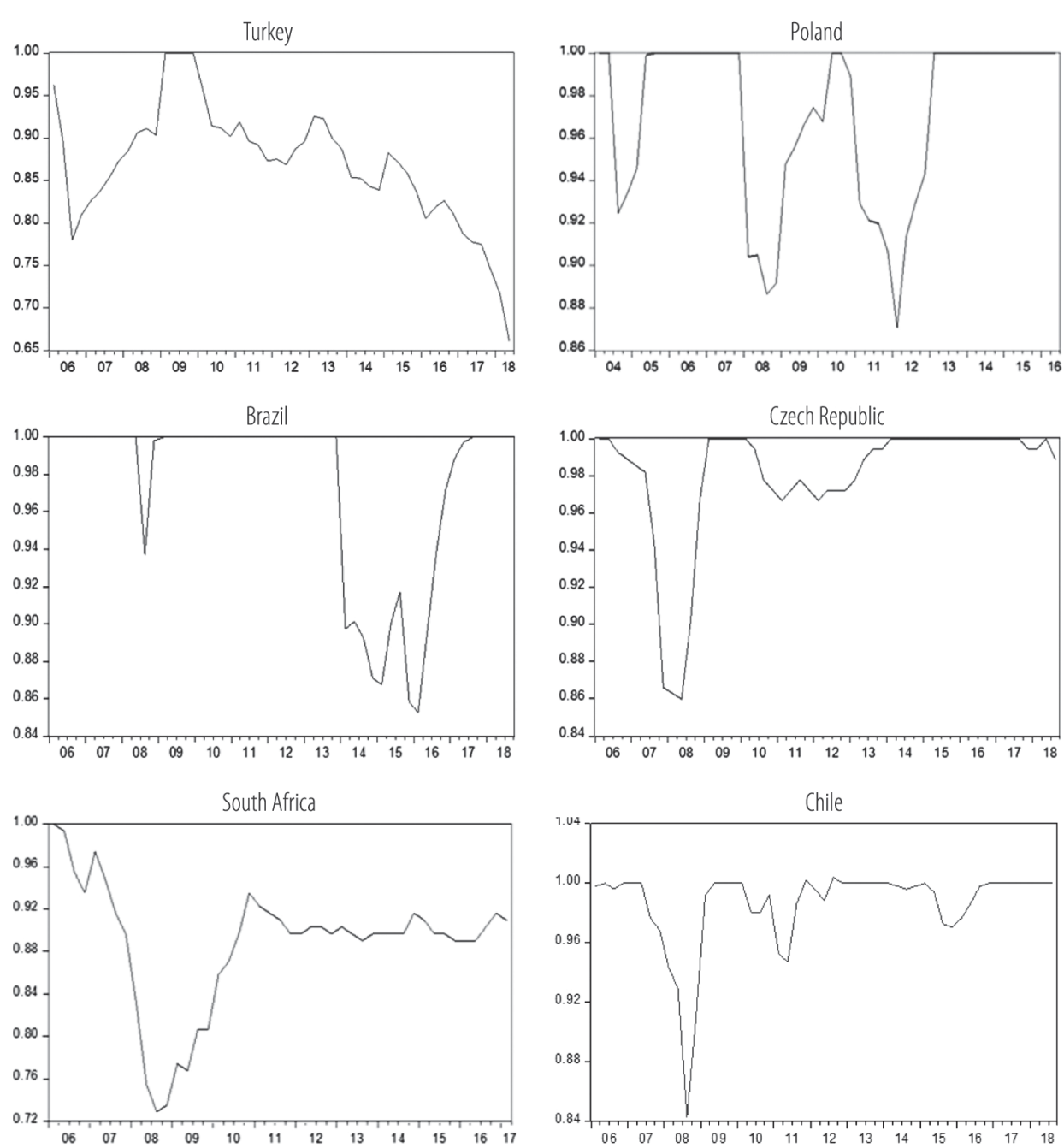

\section{Data and Sample}

Description of variables used in the model, including specific data source and descriptive statistics are presented in Appendix 1.

The credibility index (cred) calculated in the previous section was used as a proxy of credibility. For the inflation expectation variable $\left[E_{12}(\pi)\right], 12$ month ahead 
inflation expectation series collected from official websites of the Central Banks was used in the analysis. Inflation series (inf) were acquired from the OECD database as an annual growth rate of CPI (\%). The inflation target series (target) were composed off by transforming the year-end inflation targets into quarterly frequencies by the linear interpolation method. The interaction term was obtained by multiplying the inflation target variable and the credibility variable. All variables are expressed in logarithms.

Table 1: Sample countries and data ranges.

\begin{tabular}{|c|c|}
\hline Countries & Data Range \\
\hline Turkey & $2006 q 1-2018 q 2$ \\
\hline Poland & $2004 q 1-2016 q 2$ \\
\hline Brazil & $2006 q 1-2018 q 3$ \\
\hline Czech Rep. & $2006 q 1-2018 q 3$ \\
\hline South Africa & $2006 q 1-2017 q 1$ \\
\hline Chile & $2006 q 1-2018 q 3$ \\
\hline
\end{tabular}

Unit root tests were held for all the variables of each country using Dickey-Fuller test (DF) with constant, constant and trend and as well Phillips-Perron that allows autocorrelation and in error terms. Non-stationary series were used as I(1) in the analysis. The results of the performed tests are shown in Appendix 2.

\section{Methodology and Findings}

According to the theory, if the credibility of the central bank is high, economic actors are less sceptical about that the central bank can achieve the announced targets (Cukierman \& Meltzer, 1986a: 1100). Hence, as credibility increases, the speed and degree of adjustment of inflation expectations to inflation targets increases. Considering that the key principle in the success of inflation targeting is to bring inflation expectations closer to the target, high credibility facilitates the achievement of targets by increasing the anchoring strength of inflation expectations.

This section provides pieces of empirical evidence to assess the impact of credibility on inflation expectations. The evidence obtained in this section enables us to monitor whether the central bank may succeed in bringing inflation expectations closer to inflation targets by building its credibility. If the empirical findings support the theoretical claims, the central bank may strengthen the forward-looking behaviour of inflation expectations by adopting policies to improve its credibility. 
That means that inflation expectations are fed less from past inflation rates and more from inflation targets.

To make it clear that whether credibility is related to inflation expectations, OLS estimates have been made based on some variations of the model in Eq. (3) proposed by de Mendonça (2018).

$E_{t}\left(\pi_{t+4}\right)=\operatorname{cred}_{t} \times \operatorname{target}_{t+4}+\left(1-\operatorname{cred}_{t}\right) \times\left(\alpha_{1} \inf _{t-1}+\alpha_{2} i n f_{t-2}+\alpha_{3} i n f_{t-3}+\alpha_{4} i n f_{t-4}\right.$

The logic of the model in Eq. 3 based is quite simple. In the model, the weight of the inflation target is determined by the degree of credibility. As credibility increases, in the formation of inflation expectations, the weight of inflation targets increases and the weight of past inflation rates decrease. In this case, three different situations arise: As first, when credibility is full (cred=1), the weight of past inflation rates within the model is zero, in other words, inflation expectations are completely anchored to the inflation target. Secondly, when credibility is zero (cred $=0)$, the effect of inflation targets on inflation expectations is also zero. That is, inflation expectations are completely indexed to past inflation rates. Finally, in the case of a certain degree of credibility (not maximum, $0<$ cred $<1$ ), inflation expectations is adjusted to both inflation targets and past inflation rates. In this framework, credibility is the weight of the inflation target in the determination of inflation expectations and the lack of credibility is the weight of past inflation rates (de Mendonça, 2018: 9).

The models of the study are as follows:

The first model takes into account the credibility effect on inflation expectations that correspond to:

$$
E_{12}(\pi)=\alpha_{0}+\alpha_{1} \text { cred }+\varepsilon
$$

The second model excludes the credibility effect in order to observe whether only announcing an inflation target is sufficient to anchor inflation expectations, that is:

$$
E_{12}(\pi)=\beta_{0} \text { inf }+\beta_{1} \text { target }+\epsilon
$$

The third model helps us to check whether adding the credibility in the model (Eq. 5) improves the forecast performance of inflation expectations through the adjusted coefficient of determination (Adjusted R2 ):

$$
E_{12}(\pi)=\gamma_{0} \inf +\gamma_{1} \text { target }+\gamma_{2} \text { cred }+\xi
$$


The fourth and last model allows us to see whether adding credibility to inflation targets increase the anchoring strength on inflation expectations by means of an interaction term (target $\left.{ }^{*} \mathrm{cred}\right)$.

$$
E_{12}(\pi)=\rho_{0} \text { inf }+\rho_{1}(\text { target } * \text { cred })+\varsigma
$$

The results in Table 2 demonstrate that credibility has significant effects on inflation expectations in all cases. In the first model (Credibility Effect Model, Eq. 4), the credibility coefficients $\left(\alpha_{1}\right)$ are negative and have statistical significance at the 1 percent level for all countries (Column 1). This implies that inflation expectation is inversely related to credibility in all countries. Accordingly, the increase in the credibility of monetary policy ensures inflation expectations to be lowered and vice versa. Considering the fact that inflation expectations are higher than the inflation targets is a common situation in developing economies, an increase of credibility contributes to convergence inflation expectations to the target and helps the central bank to anchor expectations to the target. However, the credibility coefficients are lower in Turkey and South Africa with weak credibility performances. This result provides evidence that the impact of credibility on inflation expectations decreases as the credibility gap increases. As well, coefficient of inflation expectations is still low, and agents are more backward looking when forming their expectations.

The results of the second model (Model without Credibility, Eq. 5) are impressive in that they provide evidence that only announcing an explicit inflation target does not guarantee inflation expectations to anchor. While the coefficient of inflation $\left(\beta_{0}\right.$, Column 4$)$ is positive and statistically significant in all countries, the coefficient of the inflation target ( $\beta_{1}$, Column 5$)$ is not statistically meaningful, except in Turkey. These results imply that inflation expectations would continue to be shaped according to past inflation rates in the absence of credibility even if the inflation target is publically announced.

When compared with the Model without Credibility, the greater adjusted R2 statistics obtained from Model with Credibility in all countries (column 10) indicates that adding credibility to the model enhances forecast performance of the inflation expectations. In addition credibility coefficients $\left(y_{2}\right)$ remains significant at the 1 percent level.

The results of the Model with Interaction Term provide strong evidence of the extent to which credibility is necessary for inflation expectations to be anchored to inflation targets. While not having a meaningful effect on inflation expectations (excluding Turkey) in the second model (Column 5), after introducing credibility, inflation targets seem to have meaningful effects on the expectations. 
The interaction term (target ${ }^{*}$ cred) is positive and statistically significant in all countries. This positive relationship implies that inflation expectations move in same path as inflation targets when they explicitly involve credibility. Therefore, these results are evidence that credibility increases the anchoring strength of inflation targets on inflation expectations. Diagnostic test results were presented in Appendix 3.

These results can be regarded as evidence that the credibility increases anchoring ability of inflation targets on inflation expectations.

Table 2: Estimation results of inflation expectations

\begin{tabular}{|c|c|c|c|c|c|c|c|}
\hline \multirow{3}{*}{ Countries } & \multicolumn{4}{|c|}{$\begin{array}{l}\text { Credibility Effect Model (1) } \\
E_{12}(\pi)=\alpha_{0}+\alpha_{1} \text { cred }+\varepsilon\end{array}$} & \multicolumn{3}{|c|}{$\begin{array}{c}\text { Model without Credibility (2) } \\
E_{12}(\pi)=\beta_{0} \text { inf }+\beta_{1} \text { target }+\epsilon\end{array}$} \\
\hline & (1) & \multicolumn{2}{|c|}{ (2) } & (3) & (4) & (5) & (6) \\
\hline & $a_{0}$ & \multicolumn{2}{|c|}{$a_{1}$} & Adj. $R^{2}$ & $\beta_{0}$ & $\beta_{1}$ & Adj. $R^{2}$ \\
\hline Turkey & 0.003 & \multicolumn{2}{|c|}{$-1.57^{*}$} & 0.56 & $0.18^{*}$ & $0.42^{*}$ & 0.39 \\
\hline Poland & -0.05 & \multicolumn{2}{|c|}{$-5.63^{*}$} & 0.21 & $0.41^{*}$ & 0.007 & 0.19 \\
\hline Brazil & 0.003 & \multicolumn{2}{|c|}{$-4.18^{*}$} & 0.49 & $0.24^{* *}$ & -0.001 & 0.05 \\
\hline Czech Rep. & -0.005 & \multicolumn{2}{|c|}{$-4.85^{*}$} & 0.66 & $0.04^{* *}$ & 0.07 & 0.12 \\
\hline South Africa & 0.001 & \multicolumn{2}{|c|}{$-2.35^{*}$} & 0.97 & $0.21^{*}$ & -0.09 & 0.28 \\
\hline Chile & 0.006 & \multicolumn{2}{|c|}{$-3.89^{*}$} & 0.69 & 0.27 & 0.25 & 0.14 \\
\hline \multirow{4}{*}{ Countries } & \multicolumn{4}{|c|}{ Model with Credibility (3) } & \multicolumn{3}{|c|}{ Model with Interaction Term (4) } \\
\hline & \multicolumn{4}{|c|}{$E_{12}(\pi)=\gamma_{0}$ inf $+\gamma_{1}$ target $+\gamma_{2}$ cred $+\xi$} & \multicolumn{3}{|c|}{$E_{12}(\pi)=\rho_{0}$ inf $+\rho_{1}($ target $*$ cred $)+\varsigma$} \\
\hline & (7) & (8) & (9) & $(10)$ & (11) & $(12)$ & (13) \\
\hline & $y_{0}$ & $y_{1}$ & $y_{2}$ & Adj. $R^{2}$ & $\rho_{0}$ & $\rho_{1}$ & Adj. $R^{2}$ \\
\hline Turkey & $0.02^{* *}$ & $0.66^{*}$ & $-1.76^{*}$ & 0.96 & $0.10^{* *}$ & $0.41^{*}$ & 0.55 \\
\hline Poland & $0.29^{* *}$ & 0.008 & $-4.37^{*}$ & 0.32 & $0.30^{* *}$ & $1.17^{*}$ & 0.34 \\
\hline Brazil & 0.11 & -0.001 & $-4.07^{*}$ & 0.52 & 0.11 & $1.31^{*}$ & 0.52 \\
\hline Czech Rep. & $0.02^{* *}$ & -0.04 & $-4.69^{*}$ & 0.69 & $0.2^{* *}$ & $1.25^{*}$ & 0.71 \\
\hline South Africa & 0.01 & -0.04 & $-2.30^{*}$ & 0.96 & $0.02^{* * *}$ & $0.61^{*}$ & 0.93 \\
\hline Chile & 0.13 & -0.12 & $-3.87^{*}$ & 0.78 & 0.001 & $1.11^{*}$ & 0.78 \\
\hline
\end{tabular}

Note: $\left.\left({ }^{*}\right),{ }^{* *}\right)$ and $\left(^{* * *}\right)$ show $\% 1, \% 5$ and $\% 10$ statistical significance level respectively.

\section{Conclusion}

This study addresses the effect of monetary policy credibility on inflation expectations and the anchoring ability of inflation targets by using data of six inflation- 
targeting emerging countries (Turkey, Poland, Brazil, the Czech Republic, South Africa, and Chile). By using simple models developed on the basis of theoretical claims, the degree to which inflation expectation behaviours are influenced by past inflation rates and inflation targets have been investigated in cases where credibility exists or is absent.

This paper has presented a number of results supported by evidence showing that monetary credibility is the key piece in the monetary policy puzzle. First, an increase in credibility of the monetary policy helps to lower inflation expectations. Secondly, in the absence of credibility, inflation expectations are almost entirely shaped by past inflation rates and are further adapted to inflation targets after being integrated into the credibility. This means that the announcement of an explicit inflation target by monetary authority is not sufficient to anchor inflation expectations. However, even in the aftermath of credibility, the anchoring of inflation expectations to the targets is not full in any of the sample countries. This indicates that there exists a credibility gap in the sample country group. Moreover, in countries with poorer credibility performances (Turkey and S. Africa), the degree to which expectations are adjusted to targets is relatively low compared with the others.

When the findings are evaluated, the main conclusion of the study is that the announcement of an inflation target that is not supported by credibility would not be enough to anchor inflation expectations. Lack of credibility leads to inflation targets losing their power of being an anchor for expectations. In the event that inflation expectations get rid of the anchor, past inflation rates begin to guide expectations having backward-looking behaviour. On the other hand, through policies that eliminate the credibility gap inflation expectations may gain forward-looking behaviour by linking up to inflation targets.

Building up credibility remains a challenge for policymakers for the reason that it requires a long and challenging process. However, countries exposed to the credibility gap need to take some steps without delay. First of all, supporting the inflation target with a strong commitment is the initial step in the credibility facility. Following this step, the monetary authority should follow policies consistent with its commitment to avoid time inconsistency. In addition, there exist some common beliefs in the literature that independence, accountability, and transparency positively correlate with monetary policy credibility. These beliefs also have been supported by empirical pieces of evidence. The more public monitor and understand the policies, the more they rely on them. Therefore, a high level of transparency and extensive communication policies should be adopted to close the credibility gap. 


\section{References}

1. Aguir, A. (2018). Central bank credibility, independence, and monetary policy. Journal of Central Banking Theory and Practice, 7(3), 91-110.

2. Barro, R. J. \& Gordon, D. B. (1983). Rules, Discretion and Reputation in A Model of Monetary Policy. Journal of Monetary Economics. 12(1), 101-121.

3. Blinder, A. S. (1999). Central Bank Credibility: Why Do We Care? How Do We Build It? National Bureau of Economic Research, Working Paper 7161

4. Cecchetti, S. G. \& Krause, S. (2002). Central Bank Structure, Policy Efficiency, and Macroeconomic Performance: Exploring Empirical Relationships. Review-Federal Reserve Bank of Saint Louis, 84(4), 47-60.

5. Cukierman, A. \& Meltzer, A. H. (1986a). A Theory Of Ambiguity, Credibility, And Inflation Under Discretion and Asymmetric Information. Econometrica: Journal of The Econometric Society, 54(5), 10991128.

6. Cukierman, A. \& Meltzer, A. H. (1986b). The Credibility of Monetary Announcements. in M.J.M. Monetary Policy and Uncertainty, Ed. Neumann, Nomos-Verlagsgesellschaft, 39-68, Baden-Baden.

7. Croitorov, O (2009). Effects of Credibility of Monetary Policy: Case of Kazakhstan and Moldova", A Thesis Submitted in Partial Fulfillment of The Requirements For The Degree of MA, Kyiv School of Economics, https://kse. ua/wp-content/uploads/2019/03/Croitorov.pdf (11.09.2018).

8. de Mendonça, H. F. (2018). Credibility and Inflation Expectations: What We Can Tell From Seven Emerging Economies?. Journal of Policy Modeling, 40(6), 1165-1181.

9. Demertzis, M., Marcellino, M. \& Viegi, N. (2010). Anchors for Inflation Expectations. Europan University Institute Working Papers, Eco 2010/10, 1-18.

10. Demertzis, M. \& Viegi, N. (2016). Credibility of Central Bank(er)s. CEPR Policy Portal, Retrieved from https://voxeu.org/article/credibility-centralbankers (18.09.2018).

11. Doğan, M. K. \& Bozdemir, G. (2014). The Effects of Credibility on Interest Rates in Turkey. Eurasian Journal of Business and Economics, 7(14), 71-90.

12. Faust, J. \& Svensson, L. E. (2001). Transparency and Credibility: Monetary Policy with Unobservable Goals. International Economic Review, 42(2), 369397.

13. Friedman, B. M. (2002). The Use and Meaning of Words in Central Banking: Inflation Targeting, Credibility, and Transparency. National Bureau of Economic Research, Woking Paper No. w8972. 
14. Gürkaynak, R. S., Levin, A. \& Swanson, E. T. (2006). Does Inflation Targeting Anchor Long-run Inflation Expectations? Evidence From Longterm Bond Yields in the U.S., U.K. and Sweden”, Federal Reserve Bank of San Francisco, Working Paper No. 2006-09.

15. Issler, J. V. \& Santos, A. F. (2018). Central Bank Credibility and Inflation Expectations: A Microfounded Forecasting Approach. Retrieved From https:/editorialexpress.com/cgi-bin/conference/download.cgi?db name=IAAE2018\&paper id=547 (10.10.2018).

16. Johnson, D. R. (2002). The Effect of Inflation Targeting on The Behaviour of Expected Inflation: Evidence From an 11 Country Panel. Journal of Monetary Economics, 49(8), 1521-1538.

17. Johnson, D.R. (2003). The Effect of Inflation Targets on The Level of Expected Inflation in Five Countries. The Review of Economics and Statistics, 85(4), 1076-1081.

18. Kydland, F. E. \& Prescott, E. C. (1977). Rules Rather than Discretion: The Inconsistency of Optimal Plans. Journal of Political Economy, 85(3), 473-491.

19. Levin, A. T., Natalucci, F. M. \& Piger, J. M. (2004). The Macroeconomic Effects of Inflation Targeting. Review-Federal Reserve Bank of Saint Louis, 86(4), 51-8.

20. Mackiewicz-Łyziak, J. (2016). Central Bank Credibility: Determinants and Measurement. A Cross-Country Study. Acta Oeconomica, 66(1), 125-151.

21. Martin, V. (2020). Development of Inflation Expectations in Serbia and a Comparative Analysis. Journal of Central Banking Theory and Practice, 9(1), 61-79.

22. Radović, M., Radonjić, M., \& Đurašković, J. (2018). Central Bank Independence-The Case of the Central Bank of Montenegro. Journal of Central Banking Theory and Practice, 7(3), 25-40.

23. Svensson, L. E. (1997). Inflation Forecast Targeting: Implementing and Monitoring Inflation Targets. European Economic Review, 41(6), 1111-1146.

24. Svensson, L. E., 2009. Evaluating monetary policy (No. w15385). National Bureau of Economic Research.

25. Taylor, J. B. (1983). Comments 'Rules, Discretion And Reputation in a Model of Monetary Policy' by Robert J. Barro and David B. Gordon. Journal of Monetary Economics, 12(1), 123-125.

26. Tanuwidjaja, E. \& Choy, K. M. (2005). Central Bank Credibility and Monetary Policy: Evidence from Small Scale Macroeconomic Model of Indonesia. East Asian Bureau of Economic Research. Working Paper No.22576

27. Yuxiang, K. \& Chen, Z. (2010). Monetary Policy Credibility and Inflationary Expectation. Journal of Economic Psychology, 31(4), 487-49. 


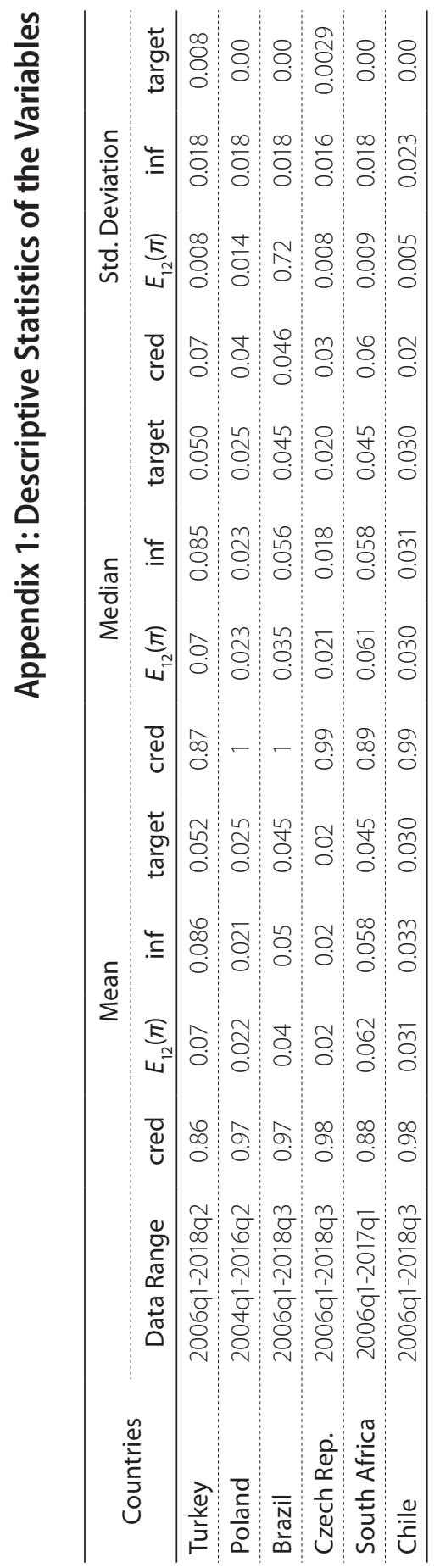




\section{Appendix 2: Unit Root Test Results}

\begin{tabular}{|c|c|c|c|c|c|c|c|c|}
\hline & \multicolumn{4}{|c|}{$A D F$} & \multicolumn{4}{|c|}{ P-P } \\
\hline & \multicolumn{2}{|c|}{ Level } & \multicolumn{2}{|c|}{ First Difference } & \multicolumn{2}{|c|}{ Level } & \multicolumn{2}{|c|}{ First Difference } \\
\hline & Cons. & Cons\&Trend & Cons. & Cons\&Trend & Cons. & Cons\&Trend & Cons. & Cons\&Trend \\
\hline \multicolumn{9}{|l|}{ Turkey } \\
\hline cred & 0.025 & -0.69 & $-5.28^{*}$ & $-5.50^{*}$ & -0.30 & -1.01 & $-5.18^{*}$ & $-5.39^{*}$ \\
\hline$E_{12}(\pi)$ & -0.60 & -0.83 & $-5.62^{*}$ & $-5.18^{*}$ & -2.19 & -2.72 & $-5.40^{*}$ & $-6.43^{*}$ \\
\hline $\inf$ & -0.65 & -0.65 & $-8.83^{*}$ & $-9.41^{*}$ & -2.62 & -2.46 & $-7.84^{*}$ & $-11.8^{*}$ \\
\hline target & $-2.87^{* * *}$ & $-3.42^{* * *}$ & $-3.18^{* *}$ & $-4.11^{* *}$ & -2.06 & -2.06 & $-4.17^{*}$ & $-4.10^{* *}$ \\
\hline \multicolumn{9}{|l|}{ Poland } \\
\hline cred & -2.38 & -2.43 & $-6.35^{*}$ & $-6.32^{*}$ & -2.65 & -2.68 & $-6.35^{*}$ & $-6.32^{*}$ \\
\hline$E_{12}(\pi)$ & -0.87 & -1.07 & $-5.07^{*}$ & $-5.11^{*}$ & -0.69 & -1.40 & $-5.06^{*}$ & $-5.11^{*}$ \\
\hline inf & -0.80 & -1.67 & $-5.05^{*}$ & $-4.95^{*}$ & -1.25 & -2.02 & $-5.04^{*}$ & $-4.94^{*}$ \\
\hline target & -1.95 & -1.54 & $-8.09^{*}$ & $-8.88^{*}$ & $-8.62^{*}$ & $-9.91^{*}$ & - & - \\
\hline \multicolumn{9}{|l|}{ Brazil } \\
\hline cred & -1.84 & -1.77 & $-6.87^{*}$ & $-6.83^{*}$ & -1.89 & -1.84 & $-6.87^{*}$ & $-6.83^{*}$ \\
\hline$E_{12}(\pi)$ & -0.87 & -1.07 & $-5.07^{*}$ & $-5.11^{*}$ & -0.69 & -1.40 & $-5.06^{*}$ & $-5.11^{*}$ \\
\hline inf & $-3.51^{*}$ & $-3.58^{* *}$ & $-3.29 * *$ & $-3.29 * *$ & -2.09 & -2.10 & $-3.40^{* *}$ & $-3.39 * *$ \\
\hline target & $-7.07^{*}$ & $-7.06^{*}$ & - & - & $-7.07^{*}$ & $-7.06^{*}$ & - & - \\
\hline \multicolumn{9}{|c|}{ Czech Republic } \\
\hline cred & -2.71 & $-3.89^{* *}$ & $-4.10^{*}$ & $-4.05^{* *}$ & -2.48 & -2.68 & $-3.65^{*}$ & $-3.60^{* *}$ \\
\hline$E_{12}(\pi)$ & -2.45 & -3.08 & $-3.74^{*}$ & $-3.72^{* *}$ & -1.80 & -2.31 & $-3.77^{*}$ & $-3.76^{* *}$ \\
\hline inf & -2.97 & -3.22 & $-5.84^{*}$ & $-5.77^{*}$ & -2.44 & -2.58 & $-4.64^{*}$ & $-4.61^{*}$ \\
\hline target & $-3.13^{*}$ & -2.94 & -1.45 & -1.59 & $-5.50^{*}$ & -2.79 & -1.45 & -1.62 \\
\hline \multicolumn{9}{|c|}{ South Africa } \\
\hline cred & -2.57 & -2.73 & $-4.19^{*}$ & $-4.26^{*}$ & -2.28 & -2.30 & $-4.19^{*}$ & $-4.29^{*}$ \\
\hline$E_{12}(\pi)$ & -2.25 & -2.36 & $-4.42^{*}$ & $-4.55^{*}$ & -2.62 & -2.58 & $-4.45^{*}$ & $-4.60^{*}$ \\
\hline inf & $-2.95^{* *}$ & -3.05 & $-4.04^{*}$ & $-4.05^{* *}$ & -2.63 & -2.62 & $-4.11^{*}$ & $-4.15^{*}$ \\
\hline target & $-6.72^{*}$ & $-6.70^{*}$ & - & - & $-6.72^{*}$ & $-6.70^{*}$ & - & - \\
\hline \multicolumn{9}{|l|}{ Chile } \\
\hline cred & -1.27 & -2.40 & $-10.5^{*}$ & $-11.9^{*}$ & $-3.13^{* *}$ & -3.27 & $-7.68^{*}$ & $-7.51^{*}$ \\
\hline$E_{12}(\pi)$ & $-4.64^{*}$ & $-4.83^{*}$ & - & - & $-3.02^{* *}$ & -3.10 & $-4.21^{*}$ & $--4.11^{*}$ \\
\hline inf & $-4.12^{*}$ & $-4.15^{*}$ & - & - & -2.68 & -2.70 & $-3.70^{*}$ & $-3.66^{* *}$ \\
\hline target & $-7.31^{*}$ & $-7.71^{*}$ & - & - & $-7.31^{*}$ & $-7.83^{*}$ & - & - \\
\hline
\end{tabular}

Note: ${ }^{*}$ and ${ }^{* *}$ shows $\% 1$ and $\% 5$ statistical significance level respectively. 


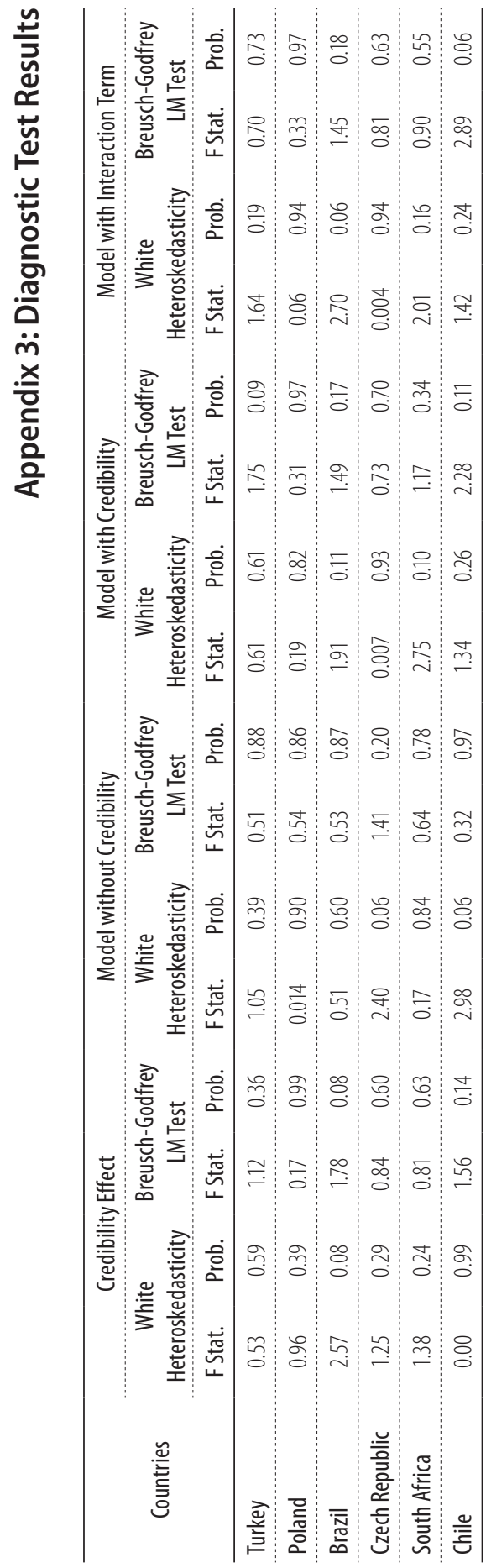

